\title{
Research on Relations between Urban Adaptability and Hometown Startups of Returned Rural Migrant Workers in the West Region
}

\author{
Taking Sichuan Province for Example
}

\author{
Dan Yang \\ School of Management \\ China West Normal University \\ Nanchong, China 637002
}

\begin{abstract}
Based on Sichuan Province, this article makes a survey on the urban adaptability and startup of returned rural migrant workers through questionnaire and mathematical statistics, drawing a conclusion as follows: The urban adaptability and wills to startup of returned rural migrant workers are of negative correlation. Surveys show rural migrant workers own sound adaptabilities when working in cities, yet having no higher wills to reside in cities permanently for development. In the meantime, rural migrant workers have lower wills and possibilities of returning home for startup, making no full preparation for the startups. According to the Push and Pull Theory, on the one hand, the startups of returned rural migrant workers are attracted and pulled by the new economic development in rural areas, on the other hand, they are pushed away due to the poor adaptabilities of working in cities. Nowadays, policies shall be strengthened to encourage rural migrant workers to return home for startups and increase the income expectation through startups, pulling them to return home for startups.
\end{abstract}

Keywords-rural migrant workers; startups at home town; Push and Pull Theory; Sichuan

\section{INTRODUCTION}

Rural migrant workers is a special social phenomenon existing in China and the state and local authorities have provided policy supports to returned migrant workers, who are encouraged to return home for startups, since 2007. With the release of such encouraging policies, industrial transfer and environmental improvement in rural areas, the startups of returned migrant workers have been a new trend and hot point attracting all eyeballs of the society. By the end of 2014, there were 274 million rural migrant workers in the country, most of whom are not permanent residents in towns or cities, and how to make rural migrant workers be local residents has become a serious problem to solve. Facing such environment, a great number of rural migrant workers need to return home due to diverse reasons, to research the startups and relevant operations of returned migrant workers will have an important

Supported by the Fundamental Research Funds of China West Normal University (Grant No. 17E010) practical significance.

In western regions in the country, the startups of returned rural migrant workers play an important role in promoting the economic development in rural areas. With rural migrant workers working in cities, they have their social networks changing as well which are mature gradually, fixed and meeting a new breakthrough, in the meantime, they have their social capitals changed and improved. Returned migrant workers have accumulated a lot of physical capitals and human capitals after working in cities, so they have been very important potential startup owners. Once returned migrant workers exert what they have had for startups, it is possible to push the startups in rural areas to a hot period. Therefore, to research the wills of rural migrant workers to return for startups and better promote them to return home for startups will have practical significance for the economic development in rural areas.

\section{LITERATURE BACKGROUND}

Ilahi (1999)[1] researched the possibility of startups of international migrants from Pakistan, the research results show the savings that the migrants have can help overcome the restrictions in loans and promote their startups. Dustmann and Kirchkamp (2002)[2]'s research results also prove that working in big cities can promote the startups of returned migrant workers, especially most international migrants from Turkey were promoted to return home for startups. Mesnard (2004) [3] researches show, under given conditions, the working and commerce in big cities may have physical capitals accumulated, which will lay a basic foundation for startups in the future. Wahba and Zenou (2012) [4] researches show international migrant workers may have their physical and human capitals accumulated, and the experience of international migrant workers may increase the possibility of startups of the returned migrant workers. Batista et al (2014)[5], based on data of Mozambique, found that the possibility of startups of returned migrant workers is high, and the possibility of returned migrant workers who come from regions where there is a tradition of migrant workers is higher. 
In China, returned migrant workers can be seen frequently, and to research the startups of returned migrant workers will have a special significance in the country. Zhao (2002) [6], based on the data of Sichuan Province, found that the investment of returned migrant workers in production is twice those who are not migrant workers. Zhou (2017) [7], based on empirical analysis, found that compared to those who are not migrant workers, returned migrant workers have higher possibility of startups. Existing researches on startups are mainly focused on decisive factors for startups of returned migrant workers (Ma, 2002) [8]. Murphy (2002)[9], based on the data of Jiangxi Province, found that the longer working experience of migrant workers will increase their savings, management skills and business connection, which will do good to their startups in the future. Démurger and $\mathrm{Xu}$ (2011)[10], based on the data of Anhui Province, researched the startup conducts of returned migrant workers, and the results show the returned migrant workers have higher possibility of startups, besides, and savings from working in big cities and working experiences will increase the probability. Zhang (2016)[11], based on the data of migrant workers from Shandong Province, conducted empirical analysis, and the results show, attitudes, social motive, achievement motive, human capital, economic capital and policy environment have positive influences on intentions of startups of returned migrant workers. Zhang(2014)[12] researched and found that the startups of returned migrant workers also fit the needs of new generations of rural migrant workers for citizen status including changes of professional status, self quality and changing traditional unscientific living styles and conducts, promoting the citizen status construction.

Seen from existing research literatures, it has turned out that the work experiences of returned rural migrant workers in cities can increase their wills in startups, promoting them for startups at home town. Facing the background that urbanization and startups in rural areas are fully supported in the country, Will rural migrant workers in city give up startups at home town due to their adaptabilities to the production and living in cities or give up permanent residences in cities due to poor adaptabilities in cities and return home for startups? Is there a necessary connection between the two? This article tries to analyze the problems and find a possible resolution.

\section{RESEARCH DESIGN}

Based on existing literatures, this article conducts questionnaires and relevant analysis. The urban adaptability mainly includes urban workers' satisfaction at working conditions, integration degree to the city and plan for permanent residents in the working city and so on; factors related to startups at home town include interests in startups at home town, startups possibility and preparation for startups and so on. Five-point Likert scale method is adopted for the two variables namely urban adaptabilities and startups at home town for migrant workers. The sample data source from the surveys on migrant workers in Sichuan, Oct 2017. Total 200 questionnaires were released, 189 of which with valid data were returned, and SPSS21.0 was used to analyze the reliabilities of problems, it was found that the Cronbach's alpha of both urban adaptability and startup intention exceed 0.7 , which indicate the data are of high reliability.

TABLE I. RELIABILITY ANALYSIS OF VARIABLES IN QUESTIONNAIRES

\begin{tabular}{|c|c|c|}
\hline Variable & Description & $\begin{array}{c}\text { Cronbach's } \\
\text { Alpha }\end{array}$ \\
\hline \multirow{3}{*}{$\begin{array}{l}\text { Urban } \\
\text { adaptabilit } \\
\mathrm{y}\end{array}$} & Satisfaction at working conditions & \multirow[t]{3}{*}{0.754} \\
\hline & Integration degree to cities & \\
\hline & Permanent residence in working cities & \\
\hline \multirow{3}{*}{$\begin{array}{l}\text { Startup } \\
\text { intention in } \\
\text { at home } \\
\text { town }\end{array}$} & Interests in startups at home town & \multirow[t]{3}{*}{0.815} \\
\hline & $\begin{array}{l}\text { Possibility of startups at home town within } \\
1-2 \text { years }\end{array}$ & \\
\hline & Preparation for startups at home town & \\
\hline
\end{tabular}

Survey results in "Table I" show, among 189 recipients, migrant workers in cities are aged 18-54, of which, those aged 20-39 account for $78.84 \%$, it turns out that most of the recipients are middle-aged and young people; the migrant workers who account for $60.32 \%$ of the total only have $0-2$ old people or children to raises in families, whose burdens are small; seen from the work nature, those who engage in management, sales and technique account for $22.75 \%, 25.4 \%$ and $22.22 \%$ respectively, which turns out most recipients tend to the service industry; within the working period in cities, those who work 10 months or more account for $44.44 \%$ of the total, which turns out most recipients have a short stay at home within a year.

\section{DATA ANALYSIS}

\section{A. Descriptive Statistics of Urban Adaptability of Migrant Workers}

First, with regard to the satisfaction at work in cities, those who are generally satisfied account for $49.7 \%$, those who are much satisfied account for $20.6 \%$, those who are very satisfied account for $1.1 \%$, those who are not satisfied account for $22.8 \%$, those who are not quite satisfied account for $5.8 \%$, the two accounts for $28.6 \%$ totally. Seen as whole, the recipients agree on work in cities, but the satisfaction degree is very low averagely $(2.88 \%)$.

Second, with regard to the integration to cities, those who are adaptable for integration account for $44.4 \%$, those who are completely adaptable for integration account for $9.0 \%$, those who are poorly adaptable for integration account for $28.0 \%$, those who are inadaptable for integration account for $16.4 \%$, those who are unable for integration account for $2.1 \%$. Generally the recipients can be integrated to the cities, and the average integration to cities is moderate (3.42).

At last, with regard to the intentions of permanent residences in cities, those who will not reside in cities account for $23.8 \%$, those who think nothing about permanent residence in cities account for $14.8 \%$. Among the migrant workers, $46.0 \%$ tend to permanent residences in cities, however, the average intention value is lower (3.11).

Generally speaking, rural migrant workers are in a good adaptability for urban lives, able to integrate the urban production and living. However, they have low satisfaction at the working conditions, and those who have intentions to permanent residencies in cities account for less than half of the 
total, which turns out that most of rural migrant workers have no long term plans for permanent residences in cities.

\section{B. Descriptive Statistics of Intentions for Startups at Home Town}

First, with regard to the interests in startups at home town, those who are interested account for $36.0 \%$, those who are much interested account for $37.6 \%$, those who are not interested account for $11.1 \%$. Seen as a whole, the recipients who have interests in starts at home account for below half of the total, and the average intentions of startups at home town is lower (2.91).

Second, with regard to the possibility of startups at home town within 1-2 years, those who are possible to return for startups account for $16.4 \%$, those who are absolutely possible to return for startups account for $2.6 \%$, the two accounts for $19.0 \%$ of the total; those who are impossible to return for startups account for $46.4 \%$, those who are absolutely impossible to return for startups account for $15.3 \%$, those who are neutral account for $19.6 \%$. Seen as a whole, the proportion of possible startups at home town is lower, and the average possible of startups at home town is lower as well (2.45).

Third, with regard to preparation for startups at home town, those who have made preparations account for $6.9 \%$, those who have made full preparations account for $1.1 \%$, the two accounts for $8.0 \%$; those who have made no preparations account for $48.1 \%$, those who have made any preparations account for $24.3 \%$, those who are moderate account for $19.6 \%$. Seen as a whole, the recipients who have made preparations for startups at home town are in a low proportion, and the average level of returning home for startups is lower as well (2.12).

Generally speaking, rural migrant workers have no great interests to startups at home town, and those who have intentions for startups at home town account for below half of the total. The possibility of returning home for startups is low, the possibility of making full preparations for returning home for startups is much lower, which turns out that most of the rural migrant workers have no full enthusiasm for returning home for startups.

\section{Analysis of Correlations between Urban Adaptability and Startups at Home Town}

In order to analyze whether the urban adaptability and startups at home town by rural migrant workers are correlated, and statistic analysis of their correlations are given in "Table II".

TABLE II. Statistics OF CORRELATIONS BETWEEN URban ADAPTABILITY AND STARTUPS AT Home TOWN

\begin{tabular}{|c|c|c|c|}
\hline Variable & $\begin{array}{c}\text { Interest in Startups } \\
\text { at Home Town }\end{array}$ & $\begin{array}{l}\text { Possibility of Returning Home } \\
\text { for Startups within 1-2 Years }\end{array}$ & $\begin{array}{c}\text { Preparations for Returning } \\
\text { Home for Startups }\end{array}$ \\
\hline \multirow{2}{*}{$\begin{array}{l}\text { Satisfaction at working } \\
\text { conditions }\end{array}$} & $-.293 * *$ & $-.268 * *$ & -.130 \\
\hline & .000 & .000 & .074 \\
\hline \multirow[t]{2}{*}{ Integration to cities } & $-.414 * *$ & $-.374 * *$ & $-.219 * *$ \\
\hline & .000 & .000 & .002 \\
\hline \multirow{2}{*}{$\begin{array}{l}\text { Intentions for permanent } \\
\text { residences in cities }\end{array}$} & $-.326 * *$ & $-.173 *$ & -.048 \\
\hline & .000 & .017 & .511 \\
\hline
\end{tabular}

Seen from "Table II", low negative correlations exist between satisfaction at working conditions and interests for returning home for startups, possibility for returning home for startups, and the correlation values between the working conditions and intentions of returning home are -0.293 and 0.268 respectively. That's to say, if rural migrant workers are satisfied at the working conditions, their intentions of returning home for startups will be low. And Obvious negative correlations exist between the integration to cities and interests of returning home for startups, possibility of returning home for startups and preparations for returning home for startups, whose correlation coefficients are $-0.414,-0.374$ and -0.219 respectively. That's to say, if rural migrant workers have higher integration to cities, their intentions of returning home for startups will be low. And obvious negative correlations exist between the intentions of permanent residences in cities and interests of returning home for startups, possibility of returning home for startups, whose correlation coefficients are $-0.326,-0.173$ respectively. Namely the stronger rural migrant workers' intentions of permanent residences in cities, the lower their intentions of returning home for startups.

\section{Explanations for Survey Results}

Based on the above-mentioned analysis, though some negative correlations exist between urban adaptability and intentions of returning home for startups by rural migrant worker, even facing the situations where startups in rural areas are supported in the country, they have no strong intentions of returning home for startups. Due to limits in resources, rural migrant workers have to consider other practical problems, after balancing diverse factors and benefits, they will decide whether to continue working in cities or return home for startups.

In 1960s, American sociologist E. S. Lee raised a modern Push-Pull theory to explain immanent causes of population migrant [13]. In his opinion, factors that influence the population migration were divided into push and pull, of which, the push is negative, because it does bad to make laborers continue lives, driving them to leave; the pull is positive, because it attracts laborers to new places for new living dreams.

According to the Push-Pull Theory raised by Lee (1966), the laborer migration is the push-pull effect between the migration-in places and migration-out-of places. Lee divided the laborers migration into four types: factors of migration-in 
places, factors of migration-out-of places, middle barriers and individual factors, which include structural and individual factors to the analysis, explaining causes of laborers migration from a wider scope, which is theoretical framework with the biggest influence on researches upon rural migrant workers in China. And the selection between working in cities and returning home startups for rural migrant workers is in a comparison between push and pull. Seen from the stage where rural migrant workers tend to working in cities, the push that there is wide poverty due to rich laborers left in rural areas in West China, casing lower income in rural areas is the first drive for rural migrant workers to work in cities. In the meantime, the high expectation and development chances in cities have attracted rural migrant workers to work. Affected by the push in rural areas and pull in cities, a great number of laborers swarm into cities for work, forming a tide of rural migrant workers. Seen from the stage where rural migrant workers return home for startups, if rural migrant workers get lower income from urban work, failing to do as expected, which will become a new push, and the expected high income and development chances to be brought by agricultural development and startups in rural areas supported by state policies will become a new pull, effected by both the push and pull, rural migrant workers will return home for startups. During the migration of rural migrant workers, when the push and pull are in the same direction, rural migrant workers will feel easy to select whether working in cities or returning home for startups. However, when the push and pull are in an adverse direction, if the push and the pull are balanced in effect, due to the difficulty to balance the overall benefits, rural migrant workers will feel difficult to select whether working in cities or returning home for startups. In this article, though negative correlations exist between the urban adaptability and returning home for startups by rural migrant workers, besides, the rural migrant workers have no higher satisfaction at the working conditions in cities, yet they have no strong intentions of returning home for startups, which turns out that rural migrant workers currently feel difficult whether to return home for startups.

\section{CONCLUSION}

Based on what mentioned above, this article draws a conclusion: (1) Rural migrant workers have fine adaptability in cities, yet having no satisfaction at working conditions and no high intentions of permanent residences in cities. (2) Rural migrant workers have no great interests in startups at home town, showing low possibility of returning home for startups and making no full preparations for startups at home town. (3) Negative correlations exist between the urban adaptability and the intentions of returning home for startups by rural migrant workers, however, rural migrant workers have difficulties in whether returning home for startups.

According the analysis on the basis of Push-Pull theory, seen from the angle to supporting rural migrant workers for startups at home, local authorities should release more policies supporting rural migrant workers for returning home for startups, bringing them higher expectation in benefits and intensifying the pull of returning home for startups, in order to better promote and drive rural migrant workers for returning home for startups.

\section{REFERENCES}

[1] Ilahi, N.,"Return migration and occupational change", Review of Development Economics,1999,3(2):170-186.

[2] Dustmann, C., and O. Kirchkam,"The optimal migration duration and activity choice after re-migration", Journal of Development Economics, 2002,67(2):351-372.

[3] Mesnard, A., "Temporary migration and capital market imperfections", Oxford Economic papers, 2004,56(2):242-262.

[4] Wahba, J., and Y Zenou, "out of sight,out of mind:migration,entrepreneurship and social capital",Regional Science and urban economics,2012,42(5):890-903.

[5] Batista,C.,T. Mcindoe-Calder,and P.Vicente, "Return migration,selfselection and entrepreneurship in Mozambique", Novafrica Working Paper Series, 1401,2014.

[6] Zhao,Y., "Causes and consequences of return migration:recent evidence from China",Journal of Comparative Economics, 2002,30(2):376394.970 .

[7] Guangsu Zhou,Huaqing Tan,Lixing Li. Does Migration experience promote entrepreneurship in rural China? China Economic Quarterly [J].2017,16(2):793-814

[8] Ma, Z., "social capital mobilization and income returns to entrepreneurship:the case of return migration in rural China",environment \& planning A,2002,34(10):1763-1784.

[9] Murphy, R., how migrant labor is changing rural China. Cambridge university press, 2002.

[10] Démurger, S., and $\mathrm{H} \mathrm{Xu}$, "Return migrants: The rise of new entrepreneurs in rural Chin",World development,2011,39(10):18471861.

[11] Zhang Li-xin, Lin Ling-zhen, Sun Kai-li. Research on the Influencing Factors of Migrant Workers' Entrepreneurial Willingness[J]. Journal of South China Agricultural University (Social Science Edition),2016,15(5):65-77.

[12] Zhang Xiu'e, sun zhongbo, the promoting effect of the returned entrepreneurial activity on the returned new generation peasant workers citizenization, journal of northeast normal university(philosophy and social science), 2014(2):37-40

[13] Everett S. Lee. A Theory of Migration. Demography,1966,vol.3:47-57. 